\title{
Women's perceived susceptibility to and utilisation of cervical cancer screening services in Malawi
}

\begin{tabular}{|c|c|}
\hline \multicolumn{2}{|c|}{$\begin{array}{l}\text { Authors: } \\
\text { Melanie Y. Hami }{ }^{1,2} \\
\text { Valerie J. Ehlers }{ }^{1} \\
\text { Dirk M. van der Wal }{ }^{1}\end{array}$} \\
\hline \multicolumn{2}{|c|}{$\begin{array}{l}\text { Affiliations: } \\
{ }^{1} \text { Department of Health } \\
\text { Studies, University of South } \\
\text { Africa, South Africa }\end{array}$} \\
\hline \multicolumn{2}{|c|}{$\begin{array}{l}{ }^{2} \text { Kamuzu College of Nursing, } \\
\text { Blantyre, Malawi }\end{array}$} \\
\hline \multicolumn{2}{|c|}{$\begin{array}{l}\text { Correspondence to: } \\
\text { Valerie Janet Ehlers }\end{array}$} \\
\hline \multicolumn{2}{|c|}{$\begin{array}{l}\text { Email: } \\
\text { ehlersjh@mweb.co.za }\end{array}$} \\
\hline \multicolumn{2}{|c|}{$\begin{array}{l}\text { Postal address: } \\
\text { PO Box } 65075 \text {, Pretoria 0165, } \\
\text { South Africa }\end{array}$} \\
\hline \multicolumn{2}{|c|}{$\begin{array}{l}\text { Dates: } \\
\text { Received: } 10 \text { Oct. } 2013 \\
\text { Accepted: } 19 \text { June } 2014 \\
\text { Published: } 24 \text { Oct. } 2014\end{array}$} \\
\hline \multicolumn{2}{|c|}{$\begin{array}{l}\text { How to cite this article: } \\
\text { Hami, M.Y., Ehlers, V.J. \& } \\
\text { Van der Wal, D.M., 2014, } \\
\text { 'Women's perceived } \\
\text { susceptibility to and } \\
\text { utilisation of cervical cancer } \\
\text { screening services in Malawi', } \\
\text { Health SA Gesondheid 19(1), } \\
\text { Art. \#787, } 8 \text { pages. http:// } \\
\text { dx.doi.org/10.4102/hsag. } \\
\text { v19i1.787 }\end{array}$} \\
\hline \multicolumn{2}{|c|}{$\begin{array}{l}\text { Copyright: } \\
\text { (C) 2014. The Authors. } \\
\text { Licensee: AOSIS } \\
\text { OpenJournals. This wor } \\
\text { is licensed under the } \\
\text { Creative Commons } \\
\text { Attribution License. }\end{array}$} \\
\hline \multicolumn{2}{|l|}{ Read online: } \\
\hline arpis & $\begin{array}{l}\text { Scan this QR } \\
\text { code with your } \\
\text { smart phone or } \\
\text { mobile device } \\
\text { to read online. }\end{array}$ \\
\hline
\end{tabular}

Background: Malawi provides cervical cancer screening services free of charge at some public health facilities. Few women make use of these cancer screening services in Malawi and many women continue to be diagnosed with cervical cancer only during the late inoperable stages of the condition.

Objectives: The purpose of this study was to discover whether the perceived susceptibility to cervical cancer, amongst Malawian women aged 42 and older, influenced their intentions to utilise the available free cervical cancer screening services.

Method: A quantitative, cross-sectional descriptive study design was adopted. Structured interviews were conducted with 381 women who visited 3 health centres in the Blantyre District of Malawi.

Results: A statistically-significant association existed between women's intentions to be screened for cervical cancer and their knowledge about cervical cancer $\left(X^{2}=8.9 ; d f=1 ; p=0.003\right)$ and with having heard about HPV infection $\left(X^{2}=4.2 ; d f=1 ; p=0.041\right)$ at the $5 \%$ significance level. Cervical cancer screening services are provided free of charge in government health institutions in Malawi. Nevertheless, low perceived susceptibility to cervical cancer amongst women, aged 42 and older, might contribute to limited utilisation of cervical screening services, explaining why $80 \%$ of cervical cancer patients in Malawi were diagnosed during the late inoperable stages.

Conclusion: Malawian women lacked awareness regarding their susceptibility to cervical cancer and required information about the available cervical cancer screening services. Malawi's women, aged 42 and older, must be informed about the advantages of cervical cancer screening and about the importance of effective treatment if an early diagnosis has been made. Women aged 42 and older rarely attend antenatal, post-natal, well baby or family-planning clinics, where health education about cervical cancer screening is often provided. Consequently, these women aged 42 and older should be informed about cervical screening tests when they utilise any health services.

Vroue se vermeende vatbaarheid en benutting van servikale kanker dienste in Malawi Agtergrond: Malawi verskaf gratis servikale kanker siftings dienste by sommige openbare gesondheids instansies. Min vrouens maak gebruik van die kanker siftings dienste in Malawi en baie vrouens word steeds gediagnoseer met servikale kanker tydens die laat onopereerbare fases van die toestand.

Doelwitte: Die doel van die studie was was om te bepaal of Malawiese vrouens wat 42 en ouer is se waargenome vatbaarheid vir servikale kanker hulle beïnvleod om beskikbare gratis servikale siftingsdienste te gebruik. 'n Kwantitatiwe, deursnee beskrywende navorsingsontwerp was gekies.

Metode: Gestruktureerde onderhoude is met 381 vrouens gevoer wat drie gesondheidsdiensentrums in die Blantyre Distrik van Malawi besoek het.

Resultate: ' $n$ Statistiese beduidende verhouding het bestaan tussen vrouens se voornemens om vir servikale kanker getoets te word en hulle kennis oor servikale kanker $\left(X^{2}=8.9\right.$; $d f=1 ; p=0.003)$ en dat hulle al gehoor het van MPV infeksies $\left(X^{2}=4.2 ; d f=1 ; p=0.041\right)$ op die $5 \%$ vlak van beduidenis. Servikale kanker siftingsdienste is gratis beskikbaar in openbare gesondheidsdiensinrigtings in Malawi. Desnieteenstaande was daar 'n lae waargenome risiko van servikale kanker onder vrouens wat 42 jaar oud en ouer was en dit het bygedra tot die beperkte benutting van siftingsdienste, wat verduidelik waarom $80 \%$ van servikale kankergevalle in Malawi gedurende die laat onopereerbare fases gediagnoseer is.

Gevolgtrekkings: Malawiese vrouens was onbewus van hulle vatbaarheid vir servikale kanker en het inligting benodig oor servikale kanker siftingsdienste. Malawi se vrouens wat 42 jaar oud en ouer is, moet ingelig word aangaande die voordele van servikale sifting en die belangrikheid van effektiewe behandeling indien ' $n$ vroë diagnose gemaak is. Vrouens van 42 of ouer benut selde voorgeboorte, nageboorte gesonde baba, of gesinsbeplanningsklinieke waar voorliging aangaande servickale kanker verskaf word. Gevolglik behoort die vrouens ingelig te word oor servikale siftingstoetse wanneer hulle enige gesondheidsdienste benut. 


\section{Introduction}

Cervical cancer is the second-most common female cancer worldwide, but the most common cancer amongst women in sub-Saharan Africa (SSA), according to Zanotti (2002). The human papillomavirus (HPV), specifically types 16 and 18, causes cervical cancer and is spread through genital contact. The principal cause of cervical cancer is infection with $\mathrm{HPV}$, acquired during sexual contact with men who may be asymptomatic carriers of HPV (Zanotti 2002). 'At least 50\% of sexually active men and women will be infected with any given type of HPV at some point in their lifetimes' (US Centers for Disease Control and Prevention, cited in Feola et al. 2012:176). Early detection of pre-invasive pathology and prompt treatment can reduce the incidence and mortality rate of cervical cancer.

Cervical cancer is a major cause of death amongst women aged 42 and older, with women in developing countries accounting for $80 \%$ of the global deaths associated with this disease (World Health Organization 2002). Failure to use cervical cancer screening services accounts for the late diagnosis of cervical cancer. In Malawi, cervical cancer accounted for approximately $28 \%$ of all female cancers, with $80 \%$ of the women with cervical cancer being diagnosed during the inoperable late stages (Dzamalala, Mdokwe \& Chimwemwe 2004:2).

\section{Health Belief Model}

The Health Belief Model (HBM) explains a person's intentions and decisions to take preventive actions, based on his or her perceived susceptibility to the disease, severity of the disease, benefits of preventive actions and barriers to taking preventive actions (Nejard, Wertheim \& Greenwood 2005:63). Modifying factors, including demographic and socio-psychological characteristics, also influence the likelihood of implementing and sustaining preventive actions (Glanz, Rimer \& Lewis 2002:52).

An association exists between low perceived risk of cervical cancer and limited utilisation of screening services (Bessler, Aung \& Jolly 2007:397). Women's perceived susceptibility to cervical cancer is influenced by their knowledge of its aetiology. Their personal beliefs about their susceptibility influence their intentions to utilise screening services for asymptomatic diseases such as early cancer (Soskolne, Marie \& Manor 2007:666). The likelihood of taking preventive action increases when the individual has a sense of perceived susceptibility or vulnerability to cervical cancer (Russell 1999:115). After receiving information on how cervical cancer is acquired and about cervical screening, women requested more frequent screening from general practitioners (Bingham et al. 2003:S408), probably because these women became aware of their potential susceptibility to cervical cancer.

\section{Problem statement}

Malawi's cervical cancer statistics for 2000-2006 indicate that out of the 3221 women diagnosed with cervical cancer,
1991 (61.8\%) were aged 42 and older. Many Malawian women, diagnosed with cervical cancer, had never been screened preceding their diagnoses, though all of them had visited government health facilities that provided cervical cancer screening services at least once during the preceding 5-10 years (Taulo, Malunga \& Ngwira 2008:141). Such visits to healthcare facilities indicate missed opportunities for the provision of cervical screening services to these women. Although Malawi's government healthcare facilities provide cervical cancer screening services free of charge, $80 \%$ of the women with cervical cancer were diagnosed during the inoperable late stages of the disease (Dzamalala et al. 2004:4).

This study thus attempted to answer the following questions: Is there an association between perceived susceptibility to cervical cancer amongst Malawian women aged 42 and older and their intentions to be screened? Which modifying factors influence women's decisions to use cervical cancer screening services in Malawi?

The objective of the study was to describe the association between perceived susceptibility to cervical cancer in women aged 42 and older and their intentions to be screened, taking into consideration modifying factors that could influence these decisions. Recommendations will be provided for enhancing women's utilisation of cervical cancer screening services in Malawi in order to reduce the mortality and morbidity associated with late diagnosis of cervical cancer.

\section{Hypotheses and null hypotheses}

Based on the problem statement, the following hypotheses were formulated:

- 'there is a positive correlation between women's perceived susceptibility to cervical cancer and their intentions to utilise cervical cancer screening services'

- 'some modifying factors influence women's decisions to use cervical cancer screening services'.

The null hypotheses stated:

- 'there is no positive correlation between women's perceived susceptibility to cervical cancer and their intentions to utilise cervical cancer screening services'

- 'no modifying factors influence women's decisions to use cervical cancer screening services'.

\section{Research method and design}

A quantitative, exploratory, cross-sectional and descriptive research design was adopted in order to obtain information from women aged 42 and older regarding their perceived susceptibility to cervical cancer and their intentions to utilise cervical cancer screening services.

\section{Research population and sample}

The population comprised all women, aged 42 and older, attending public clinics providing cervical cancer screening services in the southern region of Malawi. However, 
Malawi's Department of Health could not supply these statistics as only statistics about women at childbearing age were available. The accessible population comprised 3431 women attending the 3 participating clinics during the data-collection phase (February and March 2011), who were willing to participate in the study. All women, aged 42 and older, who arrived at the 3 participating clinics during the data-collection phase were informed about the study and invited to participate. Those 381 women who were willing to be interviewed and to sign consent forms, comprised the convenience sample for this study, amounting to $11.1 \%$ of the 3431 women who attended the 3 participating clinics during the data-collection phase.

\section{Data-collection instrument}

Section A of the structured interview schedule comprised nine closed-ended questions on demographic factors such as age, marital status, educational attainment, employment status, number of children and household income. Section B consisted of 19 closed- and open-ended questions, assessing respondents' perceptions of being susceptible to cervical cancer, their intentions to use cervical screening services, their previous utilisation of these services and their perception of cervical cancer as a health concern, as well as who should initiate cervical cancer screening.

To address validity issues, the instrument was reviewed by research and clinical experts, including two nurse/ midwives providing cervical cancer screening services in Blantyre, a statistician and two nurse researchers. The structured interview schedule was developed based on the study's objectives, literature review and the HBM's constructs. The HBM constructs addressed in this study included: individual perceptions about one's perceived susceptibility; modifying factors, including demographic and socio-psychological factors; and one's likelihood of taking action (Stanhope \& Lancaster 2000:271-272). The instrument was refined following reviews by experts and pre-testing. Five women, who attended a clinic that was not participating in this study, who were at least 42 years old and willing to be interviewed, were selected conveniently. Thus interviews with a convenience sample of five women, with similar characteristics as the women comprising the target population of this study, were used to pre-test the instrument and this information was not used in the data analysis. During the pre-test it became apparent that the interviewed women found a few words difficult to understand and complained that the interview lasted too long. Difficult words were rephrased in simpler terms and duplicate questions were eliminated. The revised instrument took about 30 minutes to complete.

Three nurses and/or midwives were trained by the researcher to recruit possible respondents, obtain informed consent and conduct interviews. The inter-rater reliability coefficient was 0.92. The Cronbach alpha coefficient, calculated for items pertaining to the women's perceived susceptibility, was 0.62 , which was deemed acceptable for making group level comparisons (Prebble 2013).

\section{Data-collection procedure}

Structured interviews were conducted with 381 women, aged 42 and older, attending clinics at the 3 health centres in Blantyre, providing cervical cancer screening services, during February and March 2011. All responses to openended questions were recorded verbatim. The interviews were conducted after women's consultations with their healthcare providers so as to avoid disruptions of women's treatment and the clinics' routines.

\section{Data analysis}

The numerical data were analysed using the computerised Statistical Package for Social Sciences (SPSS) version 16.0 (SPSS Inc., Chicago 2007). Descriptive statistics were used to summarise and describe the data. The responses to openended items were grouped and analysed quantitatively.

\section{Results}

\section{Biographical information (modifying factors)}

Not all 381 women responded to all items, explaining the varying numbers of responses for different questions. In cases where all women answered an item, $N=381$ is used, but $n$ indicates any other total number of responses and $f$ indicates a subtotal within any category $(n$ or $N)$.

\section{Respondents' ages, marital status and number of children}

The 378 respondents' ages ranged from 42 to 70 . The average age was 49.1 years and the standard deviation (SD) was 6.0. Of the respondents, $61.9 \%(f=234)$ were in the age group of $42-49$ and only $10.3 \%(f=39)$ were older than 60 . Most of the 378 respondents, $65.6 \%(f=248)$ were married, but $25.9 \%(f=98)$ were widowed, $7.4 \%(f=28)$ were divorced and only $1 \%(f=4)$ had never been married. Of the 375 respondents who answered this question, 228 (60.8\%) had 4-6 children, $75(20 \%)$ had 3 or fewer children and $72(19.2 \%)$ had 7 children or more. According to Malawi's National Statistical Office (2010:7), Malawian women bear an average of 5.7 children.

\section{Respondents' educational status}

Of the respondents, 64\% $(f=242)$ had primary school education, 20\% $(f=75)$ had no education at all, $13.5 \%$ $(f=51)$ had secondary school education and only $2.6 \%$ $(f=10)$ had college education. However, $27 \%(f=103)$ of the interviewed women stated that they could not read or write, probably because they abandoned primary school before they mastered these skills. As the duration of the respondents' primary school attendance was not recorded, it cannot be explained why 103 women, of whom 28 had attended primary school, could not read or write. 


\section{Employment status of respondents and their husbands}

Although $57.7 \%(f=218)$ of the respondents were unemployed, $28.8 \%(f=109)$ were self-employed and $13.5 \%$ $(f=51)$ were formally employed. The respondents' high unemployment rate could be a result of a lack of education as reflected by $317(83.8 \%)$ respondents with limited education, including primary level $(64 \% ; f=242)$ and no education at all $(19.8 \% ; f=75)$.

The results indicate that $49 \%(f=99)$ of the respondents' husbands were employed but only $13.5 \%(f=51)$ of the respondents were employed. As many as $33.7 \%(f=68)$ of the husbands and $28.8 \%(f=109)$ of the respondents were self-employed. Having unemployed partners might imply less financial support for the women. Of the 99 respondents whose spouses were employed, $80.8 \%(f=80)$ intended to use cervical cancer screening services compared with $62.9 \%$ $(f=22)$ whose spouses were unemployed and $57.4 \%(f=39)$ whose husbands were self-employed.

The incomes of 109 (38.5\%) of the respondents were below the Malawi poverty line of USD1.25 per day (World Bank Development Indicators 2011).

\section{Correlations between screening services and biographical characteristics}

In the age group of 45 to $49,62.5 \%$ (85 out of 136) of the women intended to be screened for cervical cancer, which has statistical significance at the $5 \%$ level $\left(X^{2}=9.9\right.$; $d f=4 ; p=0.042$ ). There was no association between women's intentions to be screened for cervical cancer and income $\left(X^{2}=1.5 ; d f=2 ; p=0.475\right)$. More respondents with 3 or fewer children intended to go for cervical screening, but this was not significant at the $5 \%$ level $\left(X^{2}=10.0 ; d f=2 ; p=0.07\right)$ (Table 1).

Statistically-significant correlations (at the 5\% level) were obtained between the respondents' intentions to use cervical cancer screening services and their:

- marital status $\left(X^{2}=18.5 ; d f=2 ; p=<0.001\right)$, with married women being more likely to use screening services than single, divorced or widowed women

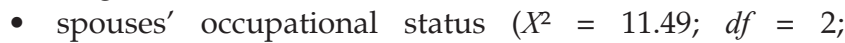
$p=<0.003)$, indicating that more women were willing to use these services if their husbands were employed

TABLE 1: Association between women's intentions to be screened for cervical cancer and demographic data.

\begin{tabular}{llll}
\hline Demographics & $X^{2}$ & $d f$ & $p$ \\
\hline Age & 9.9 & 4 & 0.042 \\
Marital status & 18.5 & 2 & 0.001 \\
Religion & 0.5 & 3 & 0.909 \\
Number of children & 10.0 & 2 & 0.07 \\
Income & 1.5 & 2 & 0.475 \\
Education level & 20.8 & 3 & 0.001 \\
Employment status & 5.4 & 2 & 0.021 \\
Within-group occupation status of the spouse & 11.5 & 2 & $<0.003$ \\
\hline
\end{tabular}

$X^{2}$, Chi-Square; $d f$, degrees of freedom; $p$, probability.
- employment status $\left(X^{2}=5.39 ; d f=2 ; p=0.021\right)$, as more employed than unemployed women would use these services

- education levels $\left(X^{2}=20.8 ; d f=3 ; p=0.001\right)$, as better educated women were more likely to use these services than those with lower education levels.

\section{Perceived susceptibility to cervical cancer}

Only $57.2 \% \quad(f=218)$ of the 381 interviewed women were planning to be screened during the following year, whilst $42.8 \%(f=163)$ did not have such plans. Of the 163 respondents who were not planning to have a cervical cancer screening test done, $17.6 \%(f=67)$ planned to have an HIV test or blood pressure check during this time, which would bring them into contact with healthcare and cervical screening services.

Out of 381 respondents, only $24.7 \%(f=94)$ had been screened for cervical cancer previously and reportedly $80 \%$ $(f=75)$ had normal results and $17 \%(f=16)$ had abnormal results, whilst $3.2 \%(f=3)$ did not know their results. For those who had not been screened, the most frequently-cited reasons from 211 respondents included not being sick and having no pain $(64 \% ; f=135)$, always being busy $(11.4 \%$; $f=24$ ) and lack of knowledge about cervical screening tests $(10 \% ; f=21)$.

Almost all respondents $(96.8 \% ; f=366)$ failed to mention HPV infection as a cause of cervical cancer. Out of the 380 respondents, 93.1\% $(f=351)$ did not know the cause of cervical cancer. However, 6.8\% $(f=26)$ claimed they did, citing traditional medicines inserted into the vagina $(27 \%$; $f=7)$, sexual intercourse $(19.2 \% ; f=5)$, sexually-transmitted infections $(15.4 \% ; f=4)$, multiple sex partners $(11.5 \% ; f=3)$ and giving birth $97.7 \% ; f=2)$, whilst $15.4 \%(f=4)$ said they had forgotten what causes cervical cancer.

Of the 377 respondents, $86.2 \%(f=325)$ did not think they were at risk of having cervical cancer, whilst only $5.8 \%$ $(f=22)$ felt they were and $8 \%(f=30)$ had no opinions about such self-perceived risks. The risk factors for cervical cancer included: sexually-transmitted infections (59.4\%; $f=190)$, smoking $(21.6 \% ; f=69)$, genetics $(13.8 \% ; f=44)$, HPV $(4.7 \%$; $f=15)$ and early age of sexual debut $(0.5 \% ; f=2)$. These findings indicate that the respondents were knowledgeable about some of the risk factors for developing cervical cancer although only $4.7 \%(f=15)$ mentioned HPV. Out of 379 respondents, $86.8 \%(f=329)$ indicated that cervical cancer was a health concern.

Some women $(24.4 \% ; f=92)$ agreed with the statement that 'if one does not have any discomfort or pain, one does not need a cervical cancer screening test' and 30\% $(f=113)$ agreed that a 'cervical cancer screening is only for sexuallyactive women'. These findings reveal some misconceptions and a lack of knowledge about cervical cancer screening. Out of 375 respondents, $49.9 \%(f=187)$ indicated that the statement 'my chances of getting cervical cancer are high' 
was 'false', 29.6\% $(f=111)$ felt that it was 'true', whilst 20.5\% $(f=77)$ indicated 'don't know'.

Potential misconceptions regarding cervical cancer screening were revealed by the following responses:

- having cervical cancer is a matter of bad luck or fate $(22 \% ; f=83)$

- cervical cancer screening is only necessary if one has a family history of cervical cancer $(7 \% ; f=26)$

- older women do not need cervical screening tests $(15.6 \%$; $f=59$ ).

There was a statistically-significant association between intention to be screened for cervical cancer and knowledge of the cause of cervical cancer at the $5 \%$ significance level $\left(X^{2}=8.9 ; d f=1 ; p=0.003\right)$ and between the intention to go for cervical cancer screening and having heard about HPV infection $\left(X^{2}=4.2 ; d f=1 ; p=0.041\right)$.

\section{Ethical considerations}

Prior to conducting the study, permission was granted by the Higher Degrees Committee of the University of South Africa (Department of Health Studies), Malawi College of Medicine (Research and Ethics Committee), the Blantyre District Health Officer and the three participating health centres' managers. Every woman who decided voluntarily to participate in the study, had the opportunity to ask questions and was informed that she could withdraw from the study at any stage and refuse to answer specific questions, without incurring any negative consequences. Written informed consent was obtained from each respondent. A private room was used for interviews and numbers instead of names were entered on completed interview schedules, maintaining anonymity of respondents. Confidentiality was maintained because all completed interview schedules were locked up and the computer's data entries were protected by a secure password. Only the researchers and the statistician had access to this information. Subsequent to the acceptance of the research report, the interview schedules and data entries would be destroyed.

\section{Discussion \\ Modifying factors \\ Marital status and parity}

All respondents were at least 42 years old, falling into the age category where cervical cancer screening is important, but where contact with healthcare services might be limited because they are unlikely to use antenatal, family planning and baby services. Women in developing countries are more likely to die from cervical cancer because women aged 42 and older might be less likely to use cervical screening services than women in developed countries (Tsu \& Levin 2008:105).

In the current study, married women were more likely to use cervical cancer screening services than single, divorced or widowed women; this was of statistical significance at the 5\% level. Lee-Lin et al. (2007:1204) found that being married or living with a partner was associated significantly with electing to have a pap test done.

Although the current study's respondents with three or fewer children were more likely to use cervical cancer screening services, this was not of statistical significance. Tsu and Levin (2008:107) reported that women with four or more children would have to fulfil numerous domestic chores, limiting their time to visit healthcare services. However, in Nene et al.'s (2007:266) study, increased parity had a significant association with the increased likelihood of using cervical cancer screening services. Consequently, previous studies seem to provide contradictory results about the correlation between women's parity and their likelihood of using cervical cancer screening services.

\section{Education levels}

Of the respondents, $84 \%(f=317)$ had no or only primary school education. These women might be unable to benefit from health promotion messages in newspapers or client information brochures. They might also have problems with regard to comprehending the aetiology and risk factors for cervical cancer. Peterson et al. (2007:1110) stated that low literacy levels correlate with less knowledge about cervical cancer screening.

In 2005 , the female literacy rate in Malawi was $52.4 \%$, with only $28 \%$ of girls aged $13-18$ attending secondary schools (White 2007:5, 11). Dropout rates for girls in primary schools continue to increase as a result of early marriages, pregnancies, home responsibilities, lack of clothing, inability to afford sanitary wear, sexual harassment by teachers as well as a lack of role models (Oster \& Thornton 2011:97; White 2007:13). A lack of education also contributes to joblessness. In the current study, 8 out of the 10 women with college education were employed, compared with one out of the 75 women who had never attended school.

\section{Employment status of respondents and their husbands}

Most respondents $(80.8 \% ; f=80)$ whose husbands were employed, intended using cervical cancer screening services. Lack of finances for transport to a health facility might be associated with low intentions to utilise preventive health services. Tsu and Levin (2008:107) stated that in both urban and rural areas in SSA, women are the main income earners in approximately one-third of households as men migrate for employment. In such circumstances, women's health is not a priority, because the survival of the family is these women's most important daily obligation (Tsu \& Levin 2008:107). More employed than unemployed women intended using cervical cancer screening services $\left(X^{2}=5.39 ; d f=2 ; p=0.021\right)$.

The current study's respondents were more likely to use cervical cancer screening services if they were married, had education beyond the primary level, were employed and had husbands who were also employed. 


\section{Perceived susceptibility to cervical cancer}

Although some respondents in the current study indicated that they knew the cause of cervical cancer, only a few $(4.7 \%$; $f=15$ ) mentioned HPV. Knowledge regarding HPV as the primary causative organism of cervical cancer, increases women's perceived susceptibility to the condition. The results of a study on college women's knowledge, perceptions and preventive behaviours regarding HPV infection and cervical cancer, demonstrated significant relationships between knowledge about HPV and behaviour. Those who had Papanicolou (Pap) tests done during the preceding year were significantly $(p<0.001)$ more knowledgeable about HPV and cervical cancer (Ingledue, Cottrell \& Bernard 2004). However, better knowledge does not necessarily translate into better utilisation of cervical cancer screening services (Ingledue et al. 2004). In Uganda, a study amongst medical workers revealed that $93 \%$ agreed that cervical cancer was a public health problem; they knew about Pap smear tests and that cervical cancer is curable if detected early. Despite this, $81 \%$ of the eligible females had never been screened, mostly because they did not feel vulnerable to cervical cancer (Mutyaba, Mmiro \& Weiderpass 2006).

In a qualitative study by Pelcastre-Villafuerte et al. (2007), women reported that cervical cancer stems from their own body and is not affected by any external agent, blaming themselves for the disease. In contrast, women attending the Margaret Pyke Center, a well-woman clinic in central London, generally knew that HPV was transmitted sexually $(64.9 \%)$ and $63.9 \%$ knew that HPV could be carried by men (Waller et al. 2003:320).

Similarly, Armstrong's (2005:170-171) exploratory study in the United Kingdom revealed that some participants felt that they were not at risk of developing cervical cancer because they had few sex partners and did not smoke or drink. The author's (Armstrong 2005:170-171) respondents indicated that HPV causes pelvic infections $(52.8 \% ; f=201)$ and cervical cancer $(15.7 \% ; f=60)$, whilst $31.7 \%(f=120)$ did not know any of the consequences of HPV infections. Armstrong's (2005:171) findings are consistent with those of a study done amongst Hispanic men and women on the Texas-Mexico border. These Hispanic participants had almost no knowledge about HPV and were unfamiliar with the condition's transmission and consequences (Fernandez et al. 2010:607).

The current study's respondents lacked knowledge about $\mathrm{HPV}$, the aetiology of cervical cancer and the necessity for using cervical cancer screening services.

\section{Limitations of the study}

This study involved only women aged 42 and older visiting the 3 health centres in Blantyre. Women who attended other cervical cancer screening clinics might have had different views. The non-probability, convenience sampling method might not, however, reflect a true representation of the characteristics of the population of Malawian women aged 42 and older.
Three research assistants conducted interviews; this could have introduced interviewer variability, although the interrater reliability coefficient was high. Only quantitative data were collected. Obtaining qualitative data through in-depth interviews might have yielded valuable data.

The cervical screening results were accepted as communicated by the respondents and could not be checked against their medical records, implying that objective test results were unavailable.

The HIV status of those respondents who had utilised cervical cancer screening services, remained unknown. Consequently it was impossible to determine whether or not HIV-infected women were more likely to suffer HPV infections and to develop cervical cancer than HIVuninfected women.

\section{Recommendations}

Recommendations based on the current study's findings will be provided in relation to nursing practice, education and future research.

Although cervical cancer screening services are provided free-of-charge in Malawi's government hospitals, few respondents $(24.7 \% ; f=94)$ had used these services and only $4.7 \%(f=15)$ knew that HPV causes cervical cancer. These findings indicate a dire need for health education in order to enhance women's knowledge regarding cervical cancer and the need for screening tests. Nurses and/or midwives in Malawi should emphasise women's susceptibility to cervical cancer and should dispel misconceptions that having cervical cancer is a matter of bad luck or fate. Cervical screening services, as well as the relevant health education, should be provided to all women attending any health facility. Women aged 42 and older are unlikely to attend the antenatal, family planning and baby clinics where nurses and/or midwives usually provide health education about cervical cancer in Malawi. Nurses and/or midwives should be able to provide cervical cancer screening services at all health facilities at all times. Providing sporadic cervical screening services on specific days during specific hours implies that there are missed opportunities to provide these services to women aged 42 and older who attend any of these health facilities. The healthcare facilities should ensure that: (1) the resources are available for Pap smears; (2) laboratory results are communicated to all women concerned; and (3) women with abnormal Pap smear results are referred to appropriate services. Health facilities that are unable to offer effective Pap smears should be enabled to offer visual inspection with acetic acid (VIA) tests. Nurse/midwives should be trained to perform both Pap and VIA tests. Referred women should be followed up so as to ensure that they have received the required treatment. Women who have been diagnosed with and treated effectively for cervical cancer could be recruited and trained to become health educators under the supervision of nurses and/or midwives. 
Malawi's general nursing, midwifery and community health curricula should emphasise the importance of early detection and effective treatment of cervical cancer. All nurses and/or midwives should be able to perform Pap and VIA tests and to refer women appropriately.

Future research should focus on women's experiences of undergoing cervical cancer screening tests through focus group and/or in-depth individual interviews, as such knowledge could help to make these services more userfriendly. Interviews should be conducted with women diagnosed with cervical cancer to find out what factors caused delays in their diagnoses and to address these factors in the healthcare services. Studies should address nurses and/or midwives' experiences of providing cervical cancer screening services in Malawi so that ways and means could be found to enhance these services.

\section{Conclusion}

Women were more likely to use cervical cancer screening services if they were employed, married to employed husbands and were educated beyond the primary school level. However, income and number of children did not significantly influence women's intentions to use these services. Thus the hypothesis that some modifying factors influenced women's intended utilisation of these services was accepted.

The other hypothesis was also accepted, namely, that women's perceived susceptibility influenced their intentions to use cervical cancer screening services. Women who did not realise that they were susceptible to cervical cancer were unlikely to use screening services. Almost all respondents (96.8\%) had inadequate knowledge about HPV and their susceptibility to cervical cancer. The respondents' lack of knowledge might have impacted negatively on their ability to prevent HPV infections and to utilise screening services for early detection and effective treatment of cervical cancer.

As long as Malawian women aged 42 and older do not perceive themselves as being susceptible to cervical cancer, they remain unlikely to use cervical cancer screening services and diagnoses of $80 \%$ of cervical cancer cases during the late inoperable stages are likely to continue in Malawi. Nurses and/or midwives could render valuable services by enhancing women's understanding of their susceptibility to cervical cancer and by offering effective cervical cancer screening services throughout Malawi to all women aged 42 and older whenever they visit health facilities.

\section{Acknowledgements}

The authors would like to acknowledge the District Health Officer, Blantyre, administration officers at the participating health centres for granting permission for the study to take place at their institutions, the data collectors for a job well done and all the women for their participation. The authors further declare that this article is based on the doctoral thesis of the first author: Hami, M.Y., 2013, Intentions to use cervical cancer screening services among women aged 42 and older in Malawi, Doctoral thesis, University of South Africa, Pretoria.

\section{Competing interests}

The authors declare that they have no financial or personal relationship(s) that may have inappropriately influenced them in writing this article.

\section{Authors' contributions}

M.Y.H. (University of South Africa) was the principal investigator who identified the need to conduct this study to help save women's lives in Malawi. She wrote the initial draft of the article and assisted with the development and processing of the article. V.J.E. (University of South Africa) was the supervisor of the study and assisted M.Y.H. throughout the study and the writing of the thesis and assumed the role of corresponding author during the development and revision of the article. D.M.vdW. (University of South Africa) was the joint supervisor of M.Y.H. and collaborated with the principal investigator and supervisor throughout all phases of the study and assisted with the drafting and revision of the article.

\section{References}

Armstrong, N., 2005, 'Resistance through risk: Women and cervical cancer screening', Health, Risk \& Society 7(2), 161-176. http://dx.doi. org/10.1080/13698570500108644

Bessler, P., Aung, M. \& Jolly, P., 2007, 'Factors affecting uptake of cervical cancer screening among clinic attendees in Trelawney, Jamaica', Cancer Control 14(4), 396-404.

Bingham, A., Bishop, A., Coffey, P., Winkler, J., Bradley, J., Dzuba, I. et al., 2003, 'Factors affecting utilization of cervical cancer prevention services in lowresource settings', Salud Pública de México 45(Suppl 3), S408-S416. http://dx.doi. org/10.1590/S0036-36342003000900015

Dzamalala, C., Mdokwe, C. \& Chimwemwe, N., 2004, Malawi cancer registry 2000-2002, Ministry of Health (Malawi), Blantyre.

Feola, T.D., Albert, M.B., Shahabi, K. \& Endy, T., 2013, 'Prevalence of HPV in HIVinfected women in the designated AIDS center at Upstate Medical University and the potential benefit of vaccination regardless of age', Journal of the Association of Nurses in AIDS Care 24(2), 176-179. http://dx.doi.org/10.1016/j. jana.2012.03.003

Fernandez, M.E., McCurdy, S.A., Arvey, S.R., Tyson, S.K., Morales-Campos, D., Flores, B. et al., 2010, 'HPV knowledge, attitudes, and cultural beliefs among Hispanic men and women living on the Texas-Mexico Border', Ethnicity \& Health 14(6), 607-624. http://dx.doi.org/10.1080/13557850903248621

Glanz, K., Rimer, B.K. \& Lewis, F.M., 2002, Health behaviour and health education: Theory, research and practice, 3rd edn., Jossey-Bass, London.

Ingledue, K., Cottrell, R. \& Bernard, A., 2004, College women's knowledge, perceptions and preventive behaviours regarding human papillomavirus infection and cervical cancer, viewed 24 August 2014, from http://www.biomedsearch.com/article/ College-womens-knowledge-perceptions-preventive/115495860.html

Lee-Lin, F., Pett, M., Menon, U., Lee, S., Nail, L., Mooney, K. et al., 2007, 'Cervical cancer beliefs and pap test screening practices among Chinese American immigrants', Oncology Nursing Forum 34(6), 1203-1209. http://dx.doi. org/10.1188/07.ONF.1203-1209

Mutyaba, T., Mmiro, F.A. \& Weiderpass, E., 2006, 'Knowledge, attitudes and practices on cervical cancer screening among the medical workers of Mulago Hospital, Uganda', BMC Medical Education 6, 13. http://dx.doi. org/10.1186/1472-6920-6-13

National Statistical Office, 2010, Malawi Demographic and Health survey. Preliminary report, Zomba, Malawi, viewed 24 August 2014, from http://dhsprogram.com/ pubs/pdf/pr4/pr4.pdf

Nejard, L.M., Wertheim, E.H. \& Greenwood, K.M., 2005, 'Comparison of the Health Belief Model and the Theory of Planned Behavior in the prediction of dieting and
fasting behaviour', E-journal of Applied Psychology: Social Section 1(1), 63-74. http://dx.doi.org/10.7790/ejap.v1i1.10

Nene, B., Jayant, K., Arrossi, S., Shastri, S., Budukh, A., Hingmire, S. et al., 2007, 'Determinants of women's participation in cervical cancer screening trial,' http://dx.doi.org/10.2471/BLT.06.031195 
Oster, E. \& Thornton, R., 2011, 'Menstruation, sanitary products, and schoo attendance: Evidence from a randomized evaluation', American Economic Journal: Applied Economics 3(1), 91-100.

Pelcastre-Villafuerte, B.E., Tirado-Gómez, L.L., Mohar-Betancourt, A. \& LópezCarvantes, M., 2007, 'Cervical cancer: A qualitative study on subjectivity, family, org/10.1186/1742-4755-4-2

Peterson, N.B., Dwyer, K.A., Mulvaney, S.A., Dietrich, M.A. \& Rothman, R.L., 2007, 'The influence of health literacy on colorectal cancer screening knowledge, beliefs and behavior', Journal of the National Medical Association 99(10), 1105-1112.

Prebble, M., 2013, Lessons from Kenya and Malawi on combining climate change, development, and population policy, viewed 24 August 2014, from http://www. newsecuritybeat.org/2013/05/lessons-kenya-malawi-combining-climate-changedevelopment-population-policy/

Russell, G., 1999, Essential psychology for nurses and other health professionals, Routledge, New York. http://dx.doi.org/10.4324/9780203264133

Soskolne, V., Marie, S. \& Manor, O., 2007, 'Beliefs, recommendations and intentions are important explanatory factors of mammography screening behavior among dx.doi.org/10.1093/her/cyl132

Stanhope, M. \& Lancaster, J., 2000, Community and public health nursing, 5th edn., Mosby, St Louis.
Taulo, F, Malunga, E \& Ngwira, A., 2008, 'Audit of gynaecological cancers at Queen Elizabeth Central Hospital, Blantyre', Malawi Medical Journal 20(4), 140-142.

Tsu, V.D. \& Levin, C.E., 2008, 'Making the case for cervical cancer prevention: What about equity?', Reproductive Health Matters 16(32), 104-112. http://dx.doi. org/10.1016/S0968-8080(08)32411-2

Waller, J., McCaffery, K., Forrest, S., Szarewski, A., Cadman, L. \& Wardle, J., 2003, 'Awareness of human papillomavirus among women attending a well woman clinic', Sexually Transmitted Infections 79(4), 320-322. http://dx.doi.org/10.1136/ sti.79.4.320

White, S., 2007, Malawi: country gender profile. Final report, viewed 24 August 2014, from http://www.jica.go.jp/english/our_work/thematic_issues/gender/ background/pdf/e07mal.pdf

World Bank Development Indicators, 2011, Malawi population below poverty line, viewed 24 August 2014, from http://www.indexmundi.com/malawi/population below_poverty_line.html

World Health Organization, 2002, Cervical cancer screening in developing countries, viewed 24 August 2014, from http://www.who.int/cancer/media/en/cancer_ cervical_37321.pdf

Zanotti, K., 2002, Endometrial, ovarian, and cervical cancer, updated page viewed 24 August 2014, from http://www.clevelandclinicmeded.com/medicalpubs/ diseasemanagement/womens-health/gynecologic-malignancies/ 